\title{
Acid-base status in canine babesiosis caused by Babesia canis
}

\author{
Marin Torti, Josipa Kuleš, Vesna Matijatko, Mirna Brkljačić, Ivana Kiš, Jelena Gotić*, \\ Vladimir Mrljak, and Iva Šmit
}

Clinic for Internal Diseases, Faculty of Veterinary Medicine, University of Zagreb, Zagreb, Croatia

TORTI, M., J. KULEŠ, V. MATIJATKO, M. BRKLJAČIĆ, I. KIŠ, J. GOTIĆ, V. MRLJAK, I. ŠMIT: Acid-base status in canine babesiosis caused by Babesia canis. Vet. arhiv 90, 603-610, 2020.

\section{ABSTRACT}

Acid-base disturbances have been reported in severe canine babesiosis caused by Babesia rossi ( $B$. rossi), but they have not been studied in babesiosis caused by $B$. canis. The objective of this study was to determine the acid-base status, blood gases and electrolyte concentrations in naturally occurring canine babesiosis caused by $B$. canis, and to compare the results to those in healthy dogs. Two groups of animals were used: group 1 consisted of 10 healthy dogs, and group 2 consisted of 14 dogs naturally infected with B. canis. The following acid-base disturbances occurred in the dogs with naturally occurring babesiosis: half of the dogs had a mixed acid-base disorder, and the other half a simple acid-base disorder. The most common mixed disorder was metabolic acidosis with metabolic alkalosis. It may be said that a variety of acid-base disorders occurs in canine babesiosis. The dogs in the present study had metabolic acidosis due to hyperlactemia and hyperchloremia, metabolic alkalosis due to hypochloremia and hypoalbuminemia, and respiratory alkalosis due to hypoxemia. With the use of the strong-ion difference approach clearer recognition of mixed acid-base disorders and their better understanding is possible.

Key words: acid-base disorders; canine babesiosis; Babesia canis; strong-ion difference

\section{Introduction}

Canine babesiosis is a tick-borne disease caused by the hemoprotozoan parasites of the genus Babesia (TABOADA and MERCHANT, 1991). Babesia parasites are classified either as large or small Babesia (KUTTLER, 1988). The large Babesia include four different species, namely, Babesia canis (B. canis), B. rossi, B. vogeli, which were earlier classified as subspecies of $B$. canis (UILENBERG et al., 1989; SCHETTERS, 2005), and Babesia sp. (Coco) (BIRKENHEUER et al., 2004; LEHTINEN et al., 2008). Thus far, several small Babesia have been identified: B. gibsoni, $B$. conradae, and "Babesia vulpes", a name suggested by BANETH et al. (2014) for the previously named Babesia "Spanish dog isolate", Babesia microtilike, Babesia (Theileria) annae, and Babesia cf. microti (ZAHLER et al., 2000; CRIADOFORNELIO et al., 2003; CAMACHO et al., 2004; KJEMTRUP et al., 2006; BECK et al., 2009; SOLANO-GALLEGO et al., 2016).

On the basis of its clinical manifestations, canine babesiosis can be either uncomplicated or complicated (LOBETTI, 1998; JACOBSON, 2006; KOSTER et al., 2015). Uncomplicated babesiosis is an acute, predominantly mild disease, characterized by pale mucous membranes, fever, anorexia,

*Corresponding author:

Assist. Prof. Jelena Gotić, PhD, DVM, Clinic for Internal Diseases, Faculty of Veterinary Medicine, University of Zagreb, Heinzelova 55, 10000 Zagreb, Croatia, Phone: +385 12390 111, E-mail: jselanec@vef.hr 
depression, splenomegaly, and hyperkinetic pulse (LOBETTI, 1998; KOSTER et al., 2015). The prognosis of the uncomplicated form is good to excellent, if treated properly with antibabesial drugs (MATIJATKO et al., 2005). The complicated form of canine babesiosis is variable in its clinical manifestations, which in turn depend on the particular complications that develop in the course of the disease. Commonly reported complications of canine babesiosis are: acute renal failure, cerebral babesiosis, coagulopathy, icterus and hepatopathy, immune-mediated hemolytic anemia (IMHA), acute respiratory distress syndrome (ARDS), hemoconcentration, shock, and multiple organ dysfunction syndrome (MODS) (MATIJATKO et al., 2005; MATIJATKO et al., 2010; KOSTER et al., 2015).

The many and varied clinical manifestations of canine babesiosis cannot be linked to an organism that is restricted solely to erythrocytes. As a result increasing numbers of authors are proposing that the diverse clinical manifestations are promoted by a common mechanism (JACOBSON and CLARK, 1994; LOBETTI, 1998) Recently it has been shown that systemic inflammatory response syndrome (SIRS), and the subsequent MODS, provide the underlying pathophysiological mechanism that is responsible for even apparently unrelated aspects of babesiosis (SCHETTERS et al., 2009; MATIJATKO et al., 2010; MATIJATKO et al., 2012).

Acid-base disturbances have been reported in severe canine babesiosis caused by $B$. rossi (LEISEWITZ et al., 1996; LEISEWITZ et al., 2001). Acidemia, alkalemia, hypokapnia, negative base excess (predominantly below the normal limit), hypoxemia and hyperlactemia have all been described in canine babesiosis caused by $B$. rossi (DE MORAIS, 1992). Regarding electrolyte status, hyperchloremia, with the subsequently lower strong ion difference between sodium and chloride concentrations, was the most common electrolyte disturbance described in the study by LEISEWITZ et al. (2001). Additionally, the most common acid-base disturbances reported in that study were concurrent metabolic acidosis and respiratory alkalosis.
Traditionally, acid-base evaluation has been viewed through theHenderson-Hasselbach equation, which focuses on the relationship between $\mathrm{pH}$, partial pressure of carbon dioxide and bicarbonate level. This approach is limited as it does not encompass all the pathophysiological changes in the metabolic component of the acid-base balance, does not relate changes in electrolyte concentration and acid-base status, and does not recognize changes in hydrogen ion concentration due to changes in plasma protein and phosphorus concentration (STEWART, 1983). Due to the limitations of the traditional approach to acid-base evaluation, Stewart proposed the strong ion difference (SID) approach, a method of analyzing metabolic acid-base imbalances (FENCL and LAITH, 1993). In this approach, a clear distinction is made between the partial pressure of carbon dioxide, SID, total concentrations of weak acids, albumin and phosphorus on the one hand (independent variables), and hydrogen ion concentration and bicarbonate levels (dependent variables) on the other. In the light of this, it is clear that changes in plasma protein concentration have to be considered in order to properly evaluate acid-base imbalances (FENCL and LAITH, 1993; RUSSEL et al., 1996).

To our knowledge, no studies regarding the acidbase status, blood gases and electrolyte disturbances in dogs infected with $B$. canis have been published. Since canine babesiosis caused by $B$. canis and canine babesiosis caused by $B$. rossi are considered to be two different diseases, the aim of the present study was to investigate these disturbances in dogs naturally infected by $B$. canis.

\section{Materials and methods}

Animals. The study was performed on two groups of animals. Group 1 consisted of 10 healthy dogs with no signs of any disease. The dogs in this group received a complete physical exam, and blood samples were taken for complete blood count and blood gases. Imidocarb dipropionate $\left(\mathrm{Imizol}^{\circledR}{ }^{\circledR}\right.$ $12 \%$, Schering-Plough) was administered in the same dose $(6 \mathrm{mg} / \mathrm{kg})$ to all of them as a preventive measure against babesiosis at the request of their owners. 
Group 2 consisted of 14 dogs naturally infected with $B$. canis, admitted to the Clinic for Internal Diseases, Faculty of Veterinary Medicine, University of Zagreb, Croatia, with clinical signs of acute babesiosis. The diagnosis of babesiosis was confirmed by demonstration of the parasites within the infected erythrocytes in thin blood smears stained with May-Grünwald-Giemsa stain. One dose $(6 \mathrm{mg} / \mathrm{kg})$ of imidocarb dipropionate was administered to all the dogs subcutaneously on the day of admission. All the dogs included in this study came from the Zagreb area, and were additionally included in a large study done by BECK et al. (2009), in which the babesia were characterized by means of polymerase chain reaction (PCR). All dogs in group 2 included in this study were infected with $B$. canis.

Samples. The blood samples for analysis were collected from the cephalic vein (for hematological analysis) and the femoral artery (for acid-base status, blood gases and electrolytes) on the day of admission. These samples were placed in tubes with EDTA for hematological analysis and into a commercial preheparinized syringe (in anaerobic conditions; PREZA-PAK ${ }^{\circledR}$ II Terumo Corporation) for acid-base and blood gas analysis. All the samples were analyzed within two hours of blood sampling, with the syringes with samples for acid-base and blood gas analysis being closed with a stop cock after sampling, and stored in a mixture of ice and water until the analysis.

Complete blood count was analyzed using an automatic hematology analyzer (System 9120; Serono Baker Diagnostic). A blood gas analyzer, Stat Profile Critical Care Xpress (CCX, Nova Biomedical, Waltham, MA, USA) was used to determine the following parameters: $\mathrm{pH}$; partial pressure of carbon dioxide $\left(\mathrm{pCO}_{2}\right)$, partial pressure of oxygen $\left(\mathrm{pO}_{2}\right)$, alveolar oxygen (A), arterial alveolar oxygen tension ratio (a/A), arterial alveolar oxygen tension gradient $\left(\mathrm{AaDO}_{2}\right)$, bicarbonate level $\left(\mathrm{HCO}_{3}^{-}\right)$, base excess of extracellular fluid (BEecf), base excess of the blood (BEb), oxygen saturation $\left(\mathrm{SO}_{2}\right)$, respiratory index $(\mathrm{RI})$, standard bicarbonate concentration (SBC), total carbon dioxide $\left(\mathrm{TCO}_{2}\right)$, partial pressure of oxygen and fraction of inspired oxygen ratio $\left(\mathrm{pO}_{2} / \mathrm{FIO}_{2}\right)$, lactate, sodium $\left(\mathrm{Na}^{+}\right)$, potassium $\left(\mathrm{K}^{+}\right)$, chloride $\left(\mathrm{Cl}^{-}\right)$, ionized calcium $\left(\mathrm{Ca}^{2+}\right)$, ionized magnesium $\left(\mathrm{Mg}^{2+}\right)$, anion gap (AG), and calcium/magnesium ratio $\left(\mathrm{Ca}^{2+} / \mathrm{Mg}^{2+}\right)$. The results were adjusted for the patient's body temperature.

Recognition of an acid-base disorder included identifying the primary acid-base disorder and the expected compensation. In cases of inappropriate compensation, a mixed acid-base disorder was suspected. The criteria for identification of an inadequate compensatory response were as follows: in a primary metabolic process, a difference in the patient's $\mathrm{pCO}_{2}$ from the expected $\mathrm{pCO}_{2}$ by more than $2 \mathrm{~mm} \mathrm{Hg}$, and a difference in the patient's $\left[\mathrm{HCO}_{3}^{-}\right]$from the expected $\left[\mathrm{HCO}_{3}^{-}\right]$by more than 2 $\mathrm{mmol} / \mathrm{L}$ in a respiratory process (DE MORAIS and LEISEWITZ 2006).

Changes in chloride concentration can result from changes in water balance or can be caused by the gain or loss of chloride. When changes in chloride are caused by water balance alterations, $\mathrm{Na}^{+}$also changes. Therefore, the patient $\mathrm{Cl}^{-}$is corrected for changes in $\mathrm{Na}^{+}$concentration (DE MORAIS and LEISEWITZ, 2006):

$$
\mathrm{Cl}_{\text {corr }}^{-}=\mathrm{Cl}_{\text {patient }}^{-} \times \mathrm{Na}_{\text {mean }}^{+} / \mathrm{Na}_{\text {patient }}^{+}
$$

The contribution of chloride to changes in $\mathrm{BE}$ and $\mathrm{HCO}_{3}^{-}$can be estimated by calculating the chloride gap, in which positive values suggest hypochloremic alkalosis, and negative values hyperchloremic acidosis:

$$
\mathrm{Cl}_{\text {gap }}^{-}=\mathrm{Cl}_{\text {mean }}^{-} \mathrm{Cl}_{\text {corr }}^{-}
$$

Estimation of SID is calculated as:

$$
\mathrm{SID}=\mathrm{Na}_{\text {mean }}^{+}-\mathrm{Cl}_{\text {corr }}^{-} \text {, }
$$

where an increase suggests metabolic alkalosis, and a decrease metabolic acidosis.

Non-cardiogenic pulmonary edema was diagnosed by the finding of crackles on auscultation of the lungs in the absence of a heart murmur, together with respiratory distress, frothy nasal discharge, and the presence of hypoxemia $\left(\mathrm{pO}_{2}<60\right.$ $\mathrm{mm} \mathrm{Hg}$ with $\mathrm{AaDO}_{2}>20 \mathrm{~mm} \mathrm{Hg}$ ).

$P C R$. DNA was extracted from $200 \mu \mathrm{L}$ of EDTA anti-coagulated whole venous blood from each dog, using a DNA blood and tissue kit (Qiagen, Hilden, Germany) according to the manufacturer's 
instructions. The PCR was performed as previously described (BECK et al., 2009).

Statistical analysis. All data were reported as mean \pm two standard deviations (2 SD) and were compared between the control dogs and the dogs with babesiosis using the Mann-Whitney U test. P values $<0.05$ were considered to be significant.

\section{Results}

Fourteen dogs fulfilled the criteria for the diagnosis of acute canine babesiosis. On the admission day, all the dogs diagnosed with babesiosis and included in this study presented with following clinical signs: depression (13/14), anorexia (10/14), pale mucous membranes (11/14), icteric mucous membranes (3/14), fever (11/14), splenomegaly (7-14), and hyperkinetic pulse (4/14). The hematological parameters are shown in Table 1, and acid-base, blood gases and electrolytes in Tables 2, 3 and 4.

Red blood cell (RBC) count, hematocrit (HMT), hemoglobin concentration and platelet (PLT) number were significantly different $(\mathrm{P}<0.05)$ in dogs with babesiosis compared to healthy dogs. In dogs with babesiosis a decrease in $\mathrm{RBC}$, hemoglobin concentration, HMT and PLT was observed (Table 1).

Table 1. Hematology parameters in healthy dogs and dogs with babesiosis

\begin{tabular}{|l|c|c|}
\hline Parameter & Healthy dogs & Infected dogs \\
\hline RBC $\left(\times 10^{12} / \mathrm{L}\right)$ & $6.8 \pm 1.52$ & $4.9 \pm 1.69^{*}$ \\
\hline HGB $(\mathrm{g} / \mathrm{L})$ & $166 \pm 21.82$ & $118 \pm 41.75^{*}$ \\
\hline HCT $(\%)$ & $48 \pm 8.91$ & $34 \pm 13.17^{*}$ \\
\hline WBC $\left(\times 10^{9} / \mathrm{L}\right)$ & $9.5 \pm 6.66$ & $7.6 \pm 10.81$ \\
\hline PLT $\left(\times 10^{9} / \mathrm{L}\right)$ & $289 \pm 262.75$ & $33 \pm 58.03^{*}$ \\
\hline
\end{tabular}

$\mathrm{RBC}=$ red blood cell count; $\mathrm{HGB}=$ hemoglobin concentration; HCT = hematocrit; WBC = white blood cell count; PLT $=$ platelet count; $*$ the infected dogs group is significantly different compared to the healthy dogs group $(\mathrm{P}<0.05)$

With regard to acid-base status, $\mathrm{BEb}$ and $\mathrm{SBC}$ were significantly different $(\mathrm{P}<0.05)$ in dogs with babesiosis compared to healthy dogs (Table 2). Blood gas analysis yielded significantly different results $(\mathrm{P}<0.05)$ of $\mathrm{a} / \mathrm{A}, \mathrm{AaDO}_{2}$, and $\mathrm{RI}$ in dogs with canine babesiosis compared to healthy dogs (Table 3).
Concentrations of $\mathrm{Na}^{+}, \mathrm{Cl}^{-}$, and lactate were also significantly different $(\mathrm{P}<0.05)$ in dogs with babesiosis when compared to healthy dogs (Table 4).

Table 2. Acid-base status parameters in healthy dogs and dogs with babesiosis

\begin{tabular}{|l|c|c|}
\hline Parameter & Healthy dogs & Infected dogs \\
\hline $\mathrm{pH}$ & $7.47 \pm 0.04$ & $7.46 \pm 0.14$ \\
\hline $\mathrm{HCO}_{3}^{-}(\mathrm{mmol} / \mathrm{L})$ & $19.7 \pm 6.06$ & $17.6 \pm 5.15$ \\
\hline $\mathrm{BEecf}(\mathrm{mmol} / \mathrm{L})$ & $-4.11 \pm 5.7$ & $-6.27 \pm 6.9$ \\
\hline $\mathrm{BEb}(\mathrm{mmol} / \mathrm{L})$ & $-1.65 \pm 4.9$ & $-4.6 \pm 6.7^{*}$ \\
\hline $\mathrm{SBC}(\mathrm{mmol} / \mathrm{L})$ & $23.1 \pm 3.3$ & $20.6 \pm 5.5^{*}$ \\
\hline
\end{tabular}

$\mathrm{HCO}_{3}^{-}=$bicarbonate concentration; BEecf $=$base excess of extracellular fluid; $\mathrm{BEb}=$ base excess of blood; $\mathrm{SBC}=$ standard bicarbonate concentration; * the infected dogs group is significantly different compared to the healthy dogs group $(\mathrm{P}<0.05)$

Table 3. Blood-gas analysis parameters in healthy dogs and dogs with babesiosis

\begin{tabular}{|c|c|c|}
\hline Parameter & Healthy dogs & Infected dogs \\
\hline $\mathrm{pCO}_{2}(\mathrm{mmHg})$ & $26.6 \pm 9.4$ & $24.4 \pm 7.3$ \\
\hline $\mathrm{pO}_{2}(\mathrm{mmHg})$ & $115 \pm 66.2$ & $90.7 \pm 48.6$ \\
\hline $\mathrm{SO}_{2}(\%)$ & $98 \pm 1.7$ & $93 \pm 23.7$ \\
\hline $\mathrm{A}(\mathrm{mmHg})$ & $114.2 \pm 11.7$ & $117.3 \pm 8.9$ \\
\hline $\mathrm{a} / \mathrm{A}(\mathrm{mmHg})$ & $0.98 \pm 0.46$ & $0.75 \pm 0.44^{*}$ \\
\hline $\mathrm{AaDO}_{2}(\mathrm{mmHg})$ & $14.4 \pm 14.1$ & $28.3 \pm 46.2^{*}$ \\
\hline RI & $0.15 \pm 0.11$ & $0.6 \pm 1.5^{*}$ \\
\hline $\mathrm{pO}_{2} / \mathrm{FIO}_{2}(\mathrm{mmHg})$ & $550.1 \pm 316.5$ & $424.2 \pm 245.5$ \\
\hline $\mathrm{TCO}_{2}(\mathrm{mmol} / \mathrm{L})$ & $20.5 \pm 6.4$ & $18.4 \pm 5.1$ \\
\hline Lactate $(\mathrm{mmol} / \mathrm{L})$ & $1.1 \pm 0.8$ & $2.1 \pm 2.8^{*}$ \\
\hline
\end{tabular}

$\mathrm{pCO}_{2}=$ partial pressure of carbon dioxide; $\mathrm{pO}_{2}=$ partial pressure of oxygen; $\mathrm{SO}_{2}=$ oxygen saturation; $\mathrm{A}=$ alveolar oxygen; $\mathrm{a} / \mathrm{A}=$ arterial alveolar oxygen tension ratio; $\mathrm{AaDO}_{2}$ $=$ arterial alveolar oxygen tension gradient; $\mathrm{RI}=$ respiratory index; $\mathrm{pO}_{2} / \mathrm{FIO}_{2}=$ partial pressure of oxygen and fraction of inspired oxygen ratio; $\mathrm{TCO}_{2}=$ total carbon dioxide; Lactate $=$ lactate concentration; * the infected dogs group is significantly different compared to the healthy dogs group $(\mathrm{P}<0.05)$ 
Table 4. Electrolyte parameters in healthy dogs and dogs with babesiosis

\begin{tabular}{|l|c|c|}
\hline Parameter & Healthy dogs & Infected dogs \\
\hline $\mathrm{Na}^{+}(\mathrm{mmol} / \mathrm{L})$ & $144 \pm 6.03$ & $138.7 \pm 9.4^{*}$ \\
\hline $\mathrm{K}^{+}(\mathrm{mmol} / \mathrm{L})$ & $4.2 \pm 0.6$ & $4 \pm 0.5$ \\
\hline $\mathrm{Cl}^{-}(\mathrm{mmol} / \mathrm{L})$ & $117.4 \pm 8.2$ & $110.7 \pm 9.8^{*}$ \\
\hline $\mathrm{Ca}^{2+}(\mathrm{mmol} / \mathrm{L})$ & $1.1 \pm 0.55$ & $1.2 \pm 0.15$ \\
\hline $\mathrm{Mg}^{2+}(\mathrm{mmol} / \mathrm{L})$ & $0.3 \pm 0.1$ & $0.3 \pm 0.1$ \\
\hline $\mathrm{AG}^{2}(\mathrm{mmol} / \mathrm{L})$ & $11.1 \pm 8.3$ & $14.3 \pm 9.5$ \\
\hline $\mathrm{Ca}^{2+} / \mathrm{Mg}^{2+}$ & $3.4 \pm 0.7$ & $3.4 \pm 0.9$ \\
\hline
\end{tabular}

$\mathrm{Na}^{+}=$sodium concentration; $\mathrm{K}^{+}=$potassium concentration; $\mathrm{Cl}^{-}$ $=$ chloride concentration; $\mathrm{Ca}^{2+}=$ ionized calcium concentration; $\mathrm{Mg}^{2+}=$ ionized magnesium concentration; $\mathrm{AG}=$ anion gap; $\mathrm{Ca}^{2+} / \mathrm{Mg}^{2+}=$ calcium/magnesium ratio; * the infected dogs group is significantly different compared to the healthy dogs group $(\mathrm{P}<0.05)$

Table 5. Calculated strong ion variables

\begin{tabular}{|l|c|c|c|}
\hline Parameter & Healthy dogs & Infected dogs & $\begin{array}{c}\text { Reference } \\
\text { range* }\end{array}$ \\
\hline $\mathrm{Cl}_{\text {corr }}$ & $117.51 \pm 12.15$ & $114.84 \pm 8.82$ & $\begin{array}{c}\text { Calculated } \\
\text { from controls }\end{array}$ \\
\hline $\mathrm{Cl}_{\text {gap }}$ & $-0.08 \pm 12.15$ & $-4.18 \pm 8.82$ & $-2.5-2.5$ \\
\hline $\mathrm{SID}$ & $26.51 \pm 12.15$ & $29.16 \pm 8.82$ & $27.1-32.2$ \\
\hline
\end{tabular}

* References published in: Leisewitz et al. (2001)

\section{Discussion}

Canine babesiosis caused by $B$. canis is an important emerging and life-threatening disease worldwide, with reported mortality rates in Europe ranging from $1.5 \%$ (France) to $20 \%$ (Hungary) (MATIJATKO et al., 2012). The mortality rate in Croatia ranges from 10 to $13.9 \%$, a rate that is similar to that reported for canine babesiosis caused by B. rossi (MATIJATKO et al., 2009). Furthermore, acid-base disorders are common in sick animals, and can significantly impact case morbidity and mortality if left unrecognized and untreated.

Arterial blood $\mathrm{pH}$ was not predictive of the acid-base status in most of the dogs in this study. Standard bicarbonate concentrations and $\mathrm{BEb}$ were lower in dogs with babesiosis, identifying metabolic acidosis, while higher $\mathrm{AaDO}_{2}$ and RI indicated respiratory alkalosis. Metabolic acidosis was found in 8 of the $14 \operatorname{dogs}(57 \%)$. Key issues were impaired oxygen delivery due to a critical
Table 6. Summary of acid-base disorders

\begin{tabular}{|l|c|c|}
\hline Acid-base disorder & $\begin{array}{c}\text { Number of } \\
\text { dogs }\end{array}$ & $\begin{array}{c}\text { Percentage } \\
\%\end{array}$ \\
\hline Metabolic acidosis & 8 & 57 \\
\hline Metabolic alkalosis & 8 & 57 \\
\hline Respiratory alkalosis & 5 & 36 \\
\hline $\begin{array}{l}\text { Metabolic acidosis and } \\
\text { metabolic alkalosis }\end{array}$ & 4 & 29 \\
\hline $\begin{array}{l}\text { Metabolic acidosis and } \\
\text { respiratory alkalosis }\end{array}$ & 2 & 14 \\
\hline $\begin{array}{l}\text { Metabolic alkalosis and } \\
\text { respiratory alkalosis }\end{array}$ & 1 & 7 \\
\hline $\begin{array}{l}\text { Simple acid-base } \\
\text { disorder }\end{array}$ & 7 & 50 \\
\hline $\begin{array}{l}\text { Mixed acid-base } \\
\text { disorder }\end{array}$ & 7 & 50 \\
\hline
\end{tabular}

When identifying the acid-base disorder in dogs with canine babesiosis, seven of the dogs had a mixed acid-base disorder, and seven had a simple acid-base disorder. The calculated SID variables are shown in Table 5. The most common mixed acid-base disorder was metabolic acidosis with metabolic alkalosis (Table 6).

reduction in hemoglobin, and generation of the lactate through anaerobic metabolism. Canine babesiosis typically causes hemolytic anemia, but can also result in multiple organ dysfunction. Loss of hemoglobin and anemia compromises the blood's buffering capacity. All but one dog in the study were anemic. Lactic acid generation due to tissue hypoxia is considered the main reason for metabolic acidosis in babesiosis (BUTTON, 1979). Abnormal carbohydrate metabolism is commonly evident in dogs with severe or complicated babesiosis, and is often associated with changes in other clinical and laboratory variables (JACOBSON and LOBETTI, 2005). Half of the dogs with metabolic acidosis had increased lactate concentration. These findings demonstrated that metabolic acidosis in babesiosis is only partially due to hyperlactemia. Metabolic acidosis can be caused by a decrease in SID as a result of hyperchloremia or increased 
concentrations of other strong anions (lactate), or by an increase in the concentration of total plasma weak acids $\left[\mathrm{A}_{\text {tot }}\right]$ as a result of hyperphosphatemia (DE MORAIS and LEISEWITZ, 2006). Babesiosis has been reported to be associated with high AG acidosis because of the observed hyperlactatemia (BUTTON, 1979). High AG metabolic acidosis may be missed due to hypoalbuminemia (SALEM and MAJAIS, 1992). In this study, we had one case of high AG acidosis, and two more cases with low albumin and high lactate concentration. Half of the dogs with metabolic acidosis had hyperchloremic acidosis with normal anion gap. Chloride is the most important extracellular strong anion. Correction of the chloride, and recognition of hyperchloremia is an important calculation for recognizing metabolic acidosis. These findings highlight the advantage of strong ion differences variables versus the traditional $\mathrm{AG}$ variable.

Metabolic alkalosis was found in 8 of the 14 dogs (57\%). Metabolic alkalosis can result from an increase in the SID caused by hypochloremia or by decrease in $\left[\mathrm{A}_{\text {tot }}\right]$ caused by hypoalbuminemia (DE MORAIS and LEISEWITZ, 2006). Concentrations of $\mathrm{Cl}^{-}$were significantly lower in dogs with babesiosis when compared to healthy dogs. This is probably caused by loss of chloride through vomiting.

Respiratory alkalosis was found in 5 of the 14 dogs $(36 \%)$. Respiratory alkalosis was reported in severe $B$. rossi infection in dogs (LEISEWITZ et al., 2001), and abnormal increased respiratory patterns in falciparum malaria in humans (ENGLISH et al., 1996; MAITLAND and MARSH, 2004). The main cause of respiratory alkalosis is hypoxemia. Hypoxemia in babesiosis in this study can be explained by anemia, hypotension, non-cardiogenic pulmonary edema and ARDS. Hypoxemia due to non-cardiogenic pulmonary edema $\left(\mathrm{pO}_{2}<60 \mathrm{~mm} \mathrm{Hg}\right.$ with $\mathrm{AaDO}_{2}>20 \mathrm{~mm} \mathrm{Hg}$ ) was diagnosed in two dogs. Dogs with respiratory alkalosis had lower oxygen saturation, partial pressure of oxygen and $\mathrm{pO}_{2} / \mathrm{FIO}_{2}$. Blood gas analysis showed significantly different $\mathrm{AaDO}_{2}$ and $\mathrm{RI}$ in dogs with canine babesiosis compared to healthy dogs. These parameters can be used to identify respiratory alkalosis in dogs. The $\mathrm{A}-\mathrm{aDO}_{2}$ parameter indicates the efficiency of the oxygen exchange process in the alveolar-capillary unit, so it is a useful parameter for respiratory syndromes and hypoxemia (KOGAN et al., 2008; SINGH et al., 2010). The respiratory index (RI), as the ratio between the alveolar-arterial oxygen gradient and the arterial oxygen partial pressure, is valuable in evaluation of the reduction of respiratory functions, and clinically as an indication of ARDS disorders (KOGAN et al., 2008).

Half of all the dogs had mixed acid-base disorder. The most common mixed disorder in this study was metabolic acidosis and metabolic alkalosis, which was found in $29 \%$ of dogs. This mixed disorder probably started with high AG metabolic acidosis, followed by vomiting and development of hypochloremic alkalosis. Hypoalbuminemia can also contribute to the mixed disorder by masking high $\mathrm{AG}$ acidosis and decreasing the $\left[\mathrm{A}_{\text {tot }}\right]$. Mixed metabolic and respiratory alkalosis occurred in one dog. Metabolic alkalosis was caused by hypochloremia and hypoalbuminemia, and dominated over respiratory alkalosis. Respiratory alkalosis caused a decrease in $\left[\mathrm{HCO}_{3}^{-}\right]$. Metabolic acidosis and respiratory alkalosis occurred in 30\% of the dogs with a mixed disorder. In one case, respiratory alkalosis was caused by pulmonary edema, and metabolic acidosis was due to hyperlactemia and hyperchloremia. In another case, acidosis was due to hyperchloremia, and alkalosis due to hypoalbuminemia.

In conclusion, dogs infected with $B$. canis have a high probability of developing an acid-base disorder. In this study, the following acid-base disorders were identified: metabolic acidosis due to hyperlactemia and hyperchloremia, metabolic alkalosis due to hypochloremia and hypoalbuminemia, and respiratory alkalosis due to hypoxemia. Half of all the dogs had mixed acid-base disorders. Furthermore, the traditional Henderson-Hasselbach approach gives an inadequate pathophysiological analysis which can lead to false diagnosis of the acid-base disorder, which is especially true with complex acid-base imbalances. The strong-ion difference approach enables recognition of mixed acid-base disorders and their better understanding. 


\section{Acknowledgments}

This work was supported by the European Structural and Investment Funds (Grant Agreement KK.01.1.16.0004).

\section{References}

BANETH, G., M. FLORIN-CHRISTENSEN, L. CARDOSO, L. SCHNITTGER (2014): Reclassification of Theileria annae as Babesia vulpes sp. nov. Parasit. Vectors 8, 207. DOI: 10.1186/s13071-015-0830-5

BECK, R., L. VOJTA, V. MRLJAK, A. MARINCULIC, A. BECK, T. ZIVICNJAK, S. M. CACCIÒ (2009): Diversity of Babesia and Theileria species in symptomatic and asymptomatic dogs in Croatia. Int. J. Parasitol. 39, 843-848. DOI: 10.1016/j.ijpara.2008.12.005

BIRKENHEUER, A. J., J. NEEL, D. RUSLANDER, M. G. LEVY, E. B. BREITSCHWERDT (2004): Detection and molecular characterization of a novel large Babesia species in a dog. Vet. Parasitol. 124, 151-160.

DOI: 10.1016/j.vetpar.2004.07.008

BUTTON, C. (1979): Metabolic and electrolyte disturbances in acute canine babesiosis. J. Am. Vet. Med. Assoc. 175, 475-479.

CAMACHO, A. T., F. J. GUITIAN, E. PALLAS, J. J. GESTAL, A. S. OLMEDA, H. K. GOETHERT, S. R. TELFORD III, A. SPIELMAN (2004): Azotemia and mortality among Babesia microti-like infected dogs. J. Vet. Intern. Med. 18, 141-146.

DOI: 10.1111/j.1939-1676.2004.tb00152.x

CRIADO-FORNELIO, A., M. A. GÓNZALEZ-DEL-RIO, A. BULING-SARAÑA, J. C. BARBARA-CARRETERO (2003): Molecular characterization of a Babesia gibsoni isolate from a Spanish dog. Vet. Parasitol. 117, 123-129.

DOI: 10.1016/j.vetpar.2003.08.006

DE MORAIS, H. A. (1992): A nontraditional approach to acidbase disorders. In: Fluid Therapy in Small Animal Practice (DiBartola, S. P., Ed.), W.B. Saunders, Philadelphia PA, pp. 297-320.

DE MORAIS, H. A., A. L. LEISEWITZ (2006): Mixed acid-base disorders. In: Fluid, electrolyte and acid-base disorders in small animal practice (DiBartola, S. P., Ed.), Elsevier, St. Louis MO, pp. 296-309.

DOI: $10.1016 / \mathrm{B} 0-72-163949-6 / 50015-1$

ENGLISH, M., C. WARUIRU, E. AMUKOYE, S. MURPHY, J. CRAWLEY, I. MWANGI, N. PESHU, K. MARSH (1996): Deep breathing in children with severe malaria: indicator of metabolic acidosis and poor outcome. Am. J. Trop. Med. Hyg. 55, 521-524.

DOI: 10.4269/ajtmh.1996.55.521

FENCL, V., D. E. LEITH (1993): Frontiers in respiratory physiology: Stewart's quantitative acid-base chemistry: Applications in biology and medicine. Respir. Physiol. 91, 1-16.

DOI: $10.1016 / 0034-5687(93) 90085-O$
JACOBSON, L. S. (2006): The South Africa form of severe and complicated canine babesiosis: Clinical advances 1994-2004. Vet. Parasitol. 138, 126-139.

DOI: 10.1016/j.vetpar.2006.01.047

JACOBSON, L. S., I. CLARK (1994): The pathophysiology of canine babesiosis; New approaches to an old puzzle. J. S. Afr. Vet. Assoc. 65, 134-145.

JACOBSON, L., R. G. LOBETTI (2005): Glucose, lactate, and pyruvate concentrations in dogs with babesiosis. Am. J. Vet. Res. 66, 224-250.

DOI: 10.2460/ajvr.2005.66.244

KJEMTRUP, A. M., K. WAYNWRIGHT, M. MILLER, R. A. CARRENO (2006): Babesia conradae sp. nov., small canine Babesia identified in California. Vet. Parasitol. 138, 103-111.

DOI: 10.1016/j.vetpar.2006.01.044

KOGAN, D. A., L. R. JOHNSON, K. E. JANDREY, R. E. POLLARD (2008): Clinical, clinicopathologic, and radiographic findings in dogs with aspiration pneumonia: 88 cases (2004-2006). J. Am. Vet. Med. Assoc. 233, 17421727.

DOI: 10.2460/javma.233.11.1742

KOSTER, L., R. LOBETTI, P. KELLY (2015): Canine babesiosis: a perspective on clinical complications, biomarkers, and treatment. Vet. Med. (Auckl.) 6, 119-128. DOI: $10.2147 /$ VMRR.S60431

KUTTLER, K. L. (1988): World-wide impact of babesiosis. In: Babesiosis of Domestic Animals and Man (Ristic, M., Ed.), CRC Press, Boca Raton FL, pp. 1-22.

DOI: 10.1201/9781351070027-1

LEHTINEN, L. E., A. J. BIRKENHEUER, R. E. DROLESKEY, P. J. HOLMAN (2008): In vitro cultivation of a newly recognized Babesia sp. in dogs in North Carolina. Vet. Parasitol. 124, 150-157.

DOI: 10.1016/j.vetpar.2007.10.022

LEISEWITZ, A. L., A. J. GUTHRIE, W. L. BERRY (1996): Evaluation of the effect of whole-blood transfusions on the oxygen status and acid-base balance of Babesia canis infected dogs using the oxygen status algorithm. J. S. Afr. Vet. Assoc. 67, 20-26.

LEISEWITZ, A. L., L. S. JACOBSON, H. S. DE MORAIS, F. REVERS (2001): The mixed acid-base disturbances of severe canine babesiosis. J. Vet. Intern. Med. 15, 445-452. DOI: 10.1111/j.1939-1676.2001.tb01573.x

LOBETTI, R. G. (1998): Canine babesiosis. Comp. Cont. Educ. Pract. Vet. 20, 418-431.

MAITLAND, K., K. MARSH (2004): Pathophysiology of severe malaria in children. Acta Tropica 90, 131-140.

DOI: 10.1016/j.actatropica.2003.11.010

MATIJATKO, V., I. KIŠ, M. TORTI, M. BRKLJAČIĆ, N. KUČER, R. BARIĆ-RAFAJ, D. GRDEN, T. ŽIVIČNJAK, V. MRLJAK (2009): Septic shock in canine babesiosis. Vet. Parasitol. 162, 263-270.

DOI: 10.1016/j.vetpar.2009.03.011 
MATIJATKO, V., I. KIŠ, M. TORTI, M. BRKLJAČIĆ, R. BARIĆ-RAFAJ, Z- ŽVORC, V. MRLJAK (2010): Systemic inflammatory response syndrome and multiple organ dysfunction syndrome in canine babesiosis. Vet. arhiv 80, 611-626.

MATIJATKO, V., M. TORTI, T. P. SCHETTERS (2012): Canine babesiosis in Europe: How many diseases? Trends Parasitol. 28, 99-105.

DOI: $10.1016 /$ j.pt.2011.11.003

MATIJATKO, V., V. MRLJAK, I. KIŠ, N. KUČER, J. FORŠEK, T. ŽIVIČNJAK, Ž. ROMIĆ, Z. ŠIMEC, J. J. CERON (2005): Evidence of an acute phase response syndrome in dogs naturally infected with Babesia canis. Vet. Parasitol. 144, 242-250.

DOI: 10.1016/j.vetpar.2006.10.004

RUSSEL, K. E., B. D. HANSEN, J. B. STEVENS (1996): Strong ion difference approach to acid-base imbalances with clinical applications to dogs and cats. Vet. Clin. North Am. Small Anim. Pract. 26, 1185-1201.

DOI: $10.1016 / \mathrm{S} 0195-5616(96) 50061-6$

SALEM, M. M., G. K. MAJAIS (1992): Gaps in the anion gap. Arch. Intern. Med. 152, 1625-1629.

DOI: $10.1001 /$ archinte.152.8.1625

SCHETTERS, T. (2005): Vaccination against canine babesiosis. Trends Parasitol. 21, 179-184.

DOI: $10.1016 /$ j.pt.2005.02.006

SCHETTERS, T. P., J. A. KLEUSKENS, J. VAN DER CROMMERT, P. W. DE LEEUW, A. L. FINIZIO, A. GORENFLOT (2009): Systemic inflammatory responses in dogs experimentally infected with Babesia canis; a haematological study. Vet. Parasitol. 162, 7-15.

DOI: 10.1016/j.vetpar.2009.02.012
SINGH, A. J., V. BRONSHTEIN, M. KHASHU, K. LEE, J. E. POTTS, J. FRIEL, P. CHESSEX (2010): Vitamin A is systemically bioavailable after intratracheal administration with surfactant in an animal model of newborn respiratory distress. Pediatr. Res. 67, 619-623.

DOI: 10.1203/PDR.0b013e3181da8fe8

SOLANO-GALlEGO, L., A. SAINZ, X. ROURA, A. ESTRADA-PEÑA, G. MIRÓ (2016): A review of canine babesiosis: the European perspective. Parasit. Vectors 9, 336.

DOI: $10.1186 / \mathrm{s} 13071-016-1596-0$

STEWART, P. A. (1983): Modern quantitative acid-base chemistry. Can. J. Physiol. Pharmacol. 61, 1444-1461. DOI: $10.1139 / \mathrm{y} 83-207$

TABOADA, J. S., R. MERCHANT (1991): Babesiosis of companion animals and man. Vet. Clin. North Am. Small Anim. Pract. 21, 103-123.

DOI: 10.1016/S0195-5616(91)50011-5

UILENBERG, G., F. F. J. FRANSSEN, N. M. PERRIE (1989): Three groups of Babesia canis distinguished and a proposal for nomenclature. Vet. Quart. 11, 33-40.

DOI: 10.1080/01652176.1989.9694194

ZAHER, M., H. RINDER, E. SCHEIN, R. GOTHE (2000): Detection of a new pathogenic Babesia microti-like species in dogs. Vet. Parasitol. 89, 241-248.

DOI: 10.1016/S0304-4017(00)00202-8

Received: 21 July 2020

Accepted: 8 September 2020

TORTI, M., J. KULEŠ, V. MATIJATKO, M. BRKLJAČIĆ, I. KIŠ, J. GOTIĆ, V. MRLJAK, I. ŠMIT: Acido-bazni status u pasa oboljelih od babezioze uzrokovane vrstom Babesia canis. Vet. arhiv 90, 603-610, 2020.

\section{SAŽETAK}

Poremećaji acido-baznog statusa opisani su u pasa oboljelih od babezioze uzrokovane vrstom Babesia rossi (B. rossi), no nisu istraživani u slučajevima babezioze u pasa uzrokovane vrstom $B$. canis. Cilj je istraživanja bio utvrditi acido-bazni status u pasa oboljelih od babezioze uzrokovane vrstom $B$. canis. U istraživanju su korištene dvije skupine životinja: prvu skupinu činilo je deset zdravih pasa, dok je drugu skupino činilo 14 pasa oboljelih od babezioze. U pasa prirodno inficiranih vrstom $B$. canis pojavili su se sljedeći poremećaji acido-bazne ravnoteže: polovica pasa imala je mješoviti poremećaj acido-bazne ravnoteže, dok je druga polovica imala jednostavni poremećaj acido-bazne ravnoteže. Najčešći mješoviti poremećaj bila je metabolička acidoza s metaboličkom alkalozom. Uzroci metaboličke acidoze bili su hiperlaktemija i hiperkloremija, metaboličke alkaloze hipokloremija i hipoalbuminemija, a respiratorne alkaloze hipoksemija. Zaključno se može reći da psi oboljeli od babezioze uzrokovane vrstom $B$. canis razvijaju poremećaj acido-baznog statusa te da se na temelju razlike jakih iona mješoviti poremećaji acido-bazne ravnoteže mogu jasnije razlikovati i bolje razumjeti.

Ključne riječi: poremećaji acido-bazne ravnoteže; babezioza pasa; Babesia canis; razlika jakih iona 